\title{
Penerapan Discovery Learning Model dengan Pendekatan Saintifik untuk Meningkatkan Kemampuan Berpikir Kritis Siswa pada Konsep Kalor dan Perpindahan Kalor
}

\author{
Desta Kartikasari, Rosane Medriati, Andik Purwanto \\ Program Studi Pendidikan Fisika JPMIPA FKIP Universitas Bengkulu \\ Jl. Raya Kandang Limun No 1 Bengkulu 38123 \\ Email: destakartikasari17@gmail.com
}

\begin{abstract}
ABSTRAK
Penelitian ini merupakan penelitian tindakan kelas yang bertujuan untuk meningkatkan aktivitas dan kemampuan berpikir kritis siswa. Subyek dalam penelitian ini adalah siswa kelas XI MIA 1 MAN 2 Kota Bengkulu yang berjumlah 31 orang. Instrumen yang digunakan dalam penelitian yaitu tes kemampuan berpikir kritis dan lembar observasi aktivitas guru dan siswa. Hasil penelitian menunjukkan bahwa aktivitas belajar dan kemampuan berpikir kritis siswa meningkat dari siklus I sampai siklus III. (1) Aktivitas belajar siswa meningkat dari skor rata-rata 24 (kategori baik) pada siklus I menjadi sebesar 26 (kategori baik) pada siklus II kemudian meningkat lagi pada siklus III menjadi 28,5 (kategori baik); (2) Kemampuan berpikir kritis siswa meningkat dari siklus I dengan persentase nilai rata-rata sebesar 72,04\% (kategori cukup) menjadi 77,96\% (kategori baik) pada siklus II, kemudian meningkat lagi menjadi 82,26\% (kategori baik) pada siklus III. Berdasarkan hasil penelitian dapat disimpulkan bahwa penerapan model discovery learning dengan pendekatan saintifik dapat meningkatkan kemampuan berpikir kritis dan aktivitas belajar siswa kelas XI MIA I MAN 2 Kota Bengkulu pada konsep kalor dan perpindahan kalor.
\end{abstract}

Kata Kunci : Discovery Learning Model, Pendekatan Saintifik, Kemampuan Berpikir Kritis, Aktivitas Belajar Siswa.

\begin{abstract}
This research was a classroom action research that aimed to increase the activity and critical thinking skills of students. The subjects in this study were students of class XI MIA 1 MAN 2 Bengkulu city which amounted to 31 students. The instruments used in this research were critical thinking skill test and observation sheet of activity of teacher and student. The results showed that learning activities and students' critical thinking skills increased from cycle I to cycle III. (1) Student's learning activity increased from the average score of 24 (good category) in cycle I to be 26 (good category) in cycle II, then increased again in cycle III to be 28,5 (good category); (2) Students' critical thinking skill increased from cycle I with percentage of average score of $72.04 \%$ (enough category) to be $77.96 \%$ (good category) in cycle II, then increased again, to be $82,26 \%$ (good category) in cycle III. Based on the results of the research it can be concluded that the implementation of discovery learning model with a scientific approach can improve the critical thinking skill and learning activities of students of class XI MIA 1 MAN 2 Bengkulu city on the concept of heat and heat transfer.
\end{abstract}

Keywords : Discovery Learning Model, Scientific Approach, Critical Thinking Skill, Student Learning Activity

\section{PENDAHULUAN}

Pendidikan merupakan suatu proses perubahan melalui proses pembelajaran baik perubahan sikap maupun perubahan perilaku seseorang. Perkembangan dalam bidang pendidikan sangat erat kaitannya dengan perkembangan ilmu pengetahuan dan teknologi (IPTEK). Perkembangan ilmu pengetahuan dan teknologi tidak dapat terlepas dari kemajuan ilmu fisika yang semakin pesat [1].

Fisika merupakan salah satu cabang sains yang didalamnya mempelajari fenomena dan gejala alam yang terjadi dalam kehidupan. Untuk memahami gejala alam tersebut, maka kemampuan berpikir analitis peserta didik dibutuhkan dan dapat dikembangkan dengan 
melatih peserta didik untuk memahami konsep fisis secara langsung. Dalam hal ini pendekatan saintifik yang dikenal sebagai karakter dari kurikulum 2013 dapat dijadikan pilihan yang patut untuk dipertimbangkan [2].

Untuk mengimplementasikan kurikulum 2013 yang menitikberatkan pada keaktifan siswa (student centered), model pembelajaran yang dipandang sejalan dan cocok dengan prinsip pendekatan saintifik salah satunya adalah model pembelajaran discovery learning [3]. Menurut Badan Pengembangan Sumber Daya Manusia Pendidikan dan Kebudayaan dan Penjaminan Mutu Pendidikan, pembelajaran discovery learning adalah pembelajaran yang terjadi bila pelajar tidak disajikan dengan pembelajaran dalam bentuk finalnya, tetapi pelajar diharapkan dapat mengorganisasi dan menemukan sendiri konsep pengetahuannya [4]. Dengan belajar penemuan maka pengetahuan yang diperoleh akan bertahan lama atau lebih mudah diingat, hasil belajar yang lebih baik dan dapat meningkatkan penalaran dan berpikir secara kritis siswa [5]. Krulik dalam Winarso \& Dewi (2017) mengatakan "kemampuan berpikir kritis merupakan bagian dari kemampuan berpikir tingkat tinggi". Siswa yang terbiasa menggunakan pemikiran dalam tingkatan yang lebih tinggi akan terbiasa membedakan antara kebenaran dan kebohongan, penampilan dan kenyataan, fakta dan opini, serta pengetahuan dan keterampilan [6].

Berdasarkan wawancara dengan guru fisika di MAN 2 Kota Bengkulu dapat diketahui bahwa sekolah tersebut sudah menggunakan kurikulum 2013 dan perangkat pembelajaran yang dibuat guru juga sudah mengacu pada kurikulum 2013. Namun implementasinya dalam pembelajaran masih kurang, dimana berdasarkan observasi yang dilakukan di kelas XI MIA 1 dapat diketahui bahwa (1) kegiatan pembelajaran masih berpusat kepada guru (teacher centered) bukan kepada siswa (student centered) dimana dalam pembelajaran siswa hanya mendengarkan dan mencatat penjelasan dari guru saja serta informasi materi pembelajaran yang didapat juga hanya dari guru, (2) keaktifan belajar siswa dalam pembelajaran masih kurang, hanya 50\% siswa yang aktif dalam pembelajaran, (3) kemampuan berpikir kritis siswa belum tergali secara maksimal, dimana siswa masih sulit dalam menetukan konsep atau rumus yang tepat sebagai langkah penyelesaian suatu persoalan, menghubungkan satu konsep dengan konsep lainnya, membuat dan mengevaluasi hipotesis serta membuat kesimpulan. Hal ini menunjukkan lemahnya kemampuan berpikir kritis siswa pada indikator memfokuskan pertanyaan, membuat dan menentukan hasil pertimbangan dan menginduksi dan mempertimbangkan hasil induksi, (4) soal tes yang biasa diberikan oleh guru merupakan soal dalam kategori standar tidak dalam kategori soal berpikir tingkat tinggi. (5) ketuntasan hasil belajar siswa belum tercapai secara optimal, dimana siswa masih banyak memperoleh nilai di bawah KKM $(<75)$ hal ini bisa dilihat dari hasil ulangan harian fisika yaitu dari 31 siswa hanya $45 \%$ saja yang tuntas yaitu sebanyak 14 siswa.

Salah satu usaha yang dapat dilakukan untuk mengatasi permasalahan diatas adalah dengan memperbaiki proses pembelajaran, dapat dilakukan dengan menerapkan model pembelajaran yang menarik dan efektif yang dapat mendorong siswa aktif dan terlibat langsung dalam menemukan sendiri konsep terkait materi pembelajaran. Seperti yang terdapat dalam kurikulum 2013 salah satu model pembelajaran yang disarankan adalah discovery learning model. Dengan menerapkan model pembelajaran tersebut, diharapkan siswa dapat terlibat aktif dalam proses pembelajaran dan melatih kemampuan berpikir kritis siswa [7]. Srianty dalam Sapitri, Kurniawan, \& Sulistri (2016) mengatakan berpikir kritis merupakan cara berpikir seseorang yang mengikuti langkah-langkah sistematis dan logis, pikiran yang logis merupakan suatu jalan pikiran yang tepat dan jitu dan sesuai dengan patokan-patokan yang dikemukakan dalam logika [8].

Berdasarkan uraian di atas, tujuan pada penelitian ini yaitu (1) untuk mendeskripsikan kemampuan berpikir kritis siswa kelas XI MAN 2 Kota Bengkulu pada konsep kalor dan perpindahan kalor melalui penerapan model discovery learning dengan pendekatan saintifik; (2) untuk mendeskripsikan aktivitas belajar siswa kelas XI MAN 2 kota bengkulu pada 
konsep kalor dan perpindahan kalor melalui penerapan model discovery learning dengan pendekatan saintifik.

\section{METODE PENELITIAN}

Penelitian ini dilakukan di MAN 2 Kota Bengkulu kelas XI MIA I pada tahun ajaran 2017-2018. Penelitian yang dilakukan adalah penelitian tindakan kelas (Classroom Action Research) dilakukan dalam bentuk siklus berulang-ulang yaitu sebanyak tiga siklus, yang terdiri dari empat komponen yaitu (1) perencanaan (planning), (2) tindakan (acting), (3) pengamatan (observing), dan (4) refleksi (reflecting). Penelitian tindakan kelas yang dimaksud dalam penelitian ini adalah penelitian tindakan yang dilakukan untuk mengetahui bagaimana tindakan yang tepat untuk meningkatkan kemampuan berpikir kritis siswa. Sehingga penelitian ini difokuskan pada tindakan-tindakan sebagai usaha agar kemampuan berpikir kritis siswa dalam pembelajaran fisika dapat meningkat.

Pada penelitian ini, instrumen tes kemampuan berpikir kritis yang digunakan berupa tes yang dilakukan setelah pembelajaran berlangsung. Analisis data kemampuan berpikir kritis diambil malalui tes dalam bentuk essay yang terdiri dari tiga soal untuk tiap siklus yang mencakup aspek-aspek kemampuan $\mathrm{C} 4$ (analyzing). Soal tersebut mengandung indikator kemampuan berpikir kritis yang akan diukur yaitu fokus pada pertanyaan, menganalisis argumen, bertanya dan menjawab pertanyaan, mengobservasi dan mempertimbangkan hasil observasi, membuat induksi dan mempertimbangkan hasil induksi, serta membuat dan menentukan hasil pertimbangan. Kemampuan berpikir kritis dapat diukur dengan penilaian seperti pada persamaan 1 .

$$
\text { Nilai yang diperoleh }=\frac{\text { Jumlah skor yang diperoleh }}{\text { Jumlah skor maksimum }} \times 100 \text {. }
$$

Kemudian nilai persen tersebut dikualifikasikan dengan menggunakan tabel 1.

Tabel 1. Kualifikasi Persentase Kemampuan Berpikir Kritis

Persentase Yang Diperoleh

\begin{tabular}{|c|c|}
\hline$x \geq 87,5 \%$ & Sangat baik \\
\hline $75 \% \leq x<87,5 \%$ & Baik \\
\hline $62,5 \% \leq x<75 \%$ & Cukup \\
\hline $50 \% \leq x<62,5 \%$ & Kurang \\
\hline$x<50 \%$ & Kurang sekali \\
\hline
\end{tabular}

Lembar observasi yang digunakan terdiri dari lembar observasi aktivitas guru dan siswa. Lembar observasi ini digunakan untuk melihat aktivitas guru dan siswa pada saat pembelajaran berlangsung dan digunakan sebagai refleksi setiap akhir siklus untuk perbaikan pada siklus selanjutnya. Untuk observasi aktivitas guru dan siswa, skor skala baik adalah 3 dan skor skala kurang adalah 1 . Jumlah butir observasi 10 maka jumlah skor tertinggi adalah 30, maka didapatkan interval penilaian aktivitas belajar siswa seperti pada tabel 2 .

Tabel 2. Interval penilaian lembar observasi aktivitas siswa

\begin{tabular}{c|c|c|} 
No Kelas & Nilai rentang & \multicolumn{1}{c}{ Interpretasi Penilaian } \\
\hline $\mathbf{1}$ & $10-16$ & Kurang \\
\hline $\mathbf{2}$ & $17-23$ & Cukup \\
\hline $\mathbf{3}$ & $24-30$ & Baik \\
\hline
\end{tabular}

Untuk menghiyung nilai rata-rata penilaian aktivitas guru dan siswa dapat dihitung dengan menggunakan persamaan 2 .

$$
X=\frac{\sum\left(P_{1}+P_{2}\right)}{2} \text {. }
$$

Keterangan:

$\mathrm{X}=$ Nilai rata-rata

$\sum P_{1} \quad=$ Total skor pengamat satu

$\sum P_{2} \quad=$ Total skor pengamat dua 


\section{HASIL DAN PEMBAHASAN}

\subsection{Aktivitas Belajar Siswa}

Aktivitas belajar siswa merupakan seluruh kegiatan siswa selama proses pembelajaran berlangsung. Aktivitas belajar siswa dinilai oleh dua orang pengamat/observer menggunakan lembar observasi aktivitas belajar siswa. Data observasi aktivitas belajar siswa pada penerapan model discovery learning dengan pendekatan saintifik dari tiga siklus yang telah dilaksanakan dapat dilihat pada tabel 3.

Tabel 3. Data Observasi Aktivitas Belajar Siswa Tiga Siklus

\section{Siklus Pengamat 1 Pengamat 2 Rata-Rata Skor Kriteri}

\begin{tabular}{|c|c|c|c|c|}
\hline \multicolumn{1}{|c}{ I } & 24 & 24 & 24 & a \\
\hline II & 26 & 26 & 26 & Baik \\
\hline III & 29 & 28 & 28,5 & Baik \\
\hline
\end{tabular}

Berdasarkan tabel 3 di atas dapat diketahui bahwa aktivitas belajar siswa terus meningkat pada tiap siklusnya dan dari siklus I sampai siklus III kriteria aktivitas belajar siswa selalu berada dalam katergori baik. Rata-rata skor aktivitas guru siklus I diperoleh yaitu 24, meningkat pada siklus II yaitu 26 dan mengalami peningkatan lagi pada siklus III yaitu dengan rata-rata skor sebesar 28,5. Peningkatan aktivitas belajar siswa ini karena telah dilakukan refleksi pada tiap akhir siklus sebagai perbaikan untuk siklus berikutnya. Secara keseluruhan aktivitas belajar yang dilakukan oleh siswa sudah berjalan dengan baik dari siklus I, siklus II dan siklus III, hal ini ditandai dengan peningkatan skor rata-rata di tiap siklusnya dapat dilihat pada gambar 1 .

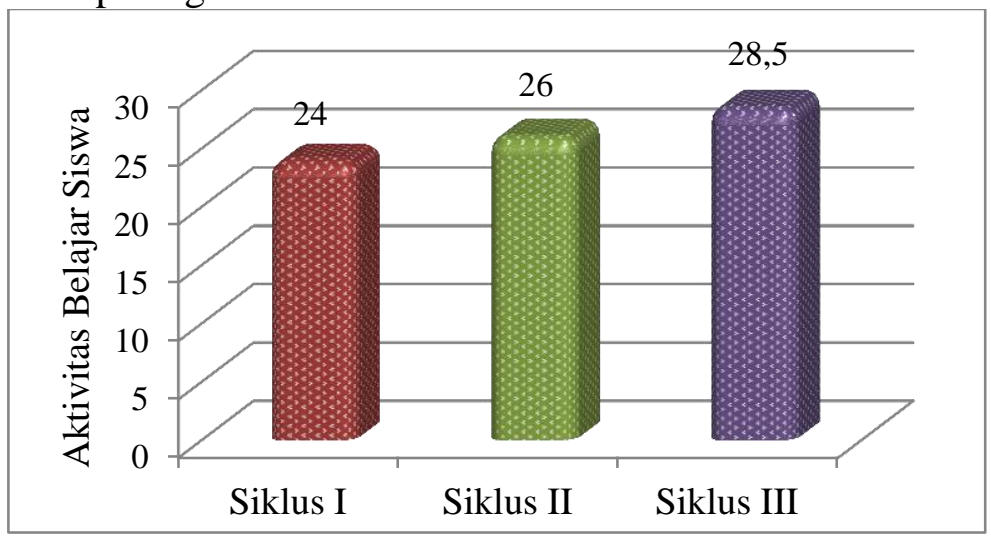

Gambar 1. Grafik Skor Rata-Rata Aktivitas Belajar Siswa

Berdasarkan uraian di atas, hasil penelitian yang diperoleh sesuai dengan penelitian yang dilakukan oleh Istiana, Catur, \& Sukardjo (2015) yang menyimpulkan bahwa model pembelajaran discovery learning dapat meningkatkan aktivitas belajar siswa [9]. Melalui model discovery learning dengan pendekatan saintifik, siswa diberikan kesempatan untuk berpikir, menemukan, berpendapat dan saling bekerja sama melalui aktivitas belajar secara ilmiah, sehingga dapat melatih dan meningkatkan kemampuan berpikir kritis siswa dan pemecahan masalah serta mendapatkan pengetahuan konsep-konsep penting [5].

\subsection{Kemampuan Berpikir Kritis Siswa}

Kemampuan berpikir kritis siswa diukur dengan memberikan soal tes kemampuan berpikir kritis berbentuk soal uraian yang berjumlah tiga butir soal. Tiap butir soal mengandung dua indikator kemampuan berpikir kritis, jadi terdapat enam indikator berpikir kritis yang diukur yaitu indikator memfokuskan pertanyaan, menganalisis argumen, bertanya dan menjawab pertanyaan, mengobservasi dan mempertimbangkan hasil observasi, membuat induksi dan mempertimbangkan hasil induksi serta membuat dan menentukan hasil pertimbangan. Nilai akhir kemampuan berpikir kritis siswa diperoleh dari persentase rata-rata nilai tes kemampuan berpikir kritis siswa, kemudian hasil dari tes dikategorikan sesuai 
dengan skala penilaian kemampuan berpikir kritis. Data hasil kemampuan berpikir kritis siswa dari siklus I sampai siklus III dapat dilihat pada tabel 4.

Tabel 4. Persentase Rata-Rata Kemampuan Berpikir Kritis Siswa Tiga Siklus

\begin{tabular}{|c|c|c|c|c|c|}
\hline \multirow[b]{2}{*}{ No } & \multirow[b]{2}{*}{ Aspek KBK } & \multirow[b]{2}{*}{ Indikator KBK } & \multicolumn{3}{|c|}{ Persentase KBK } \\
\hline & & & $\begin{array}{c}\text { Siklus } \\
\text { I }\end{array}$ & $\begin{array}{c}\text { Siklus } \\
\text { II }\end{array}$ & $\begin{array}{l}\text { Siklus } \\
\text { III }\end{array}$ \\
\hline \multirow[t]{3}{*}{1} & \multirow{3}{*}{$\begin{array}{l}\text { Elementary } \\
\text { Clarification } \\
\text { (memberikan penjelasan } \\
\text { sederhana) }\end{array}$} & Memfokuskan Pertanyaan & $87,10 \%$ & $89,68 \%$ & $94,84 \%$ \\
\hline & & Menganalisis Argumen & $73,55 \%$ & $76,77 \%$ & $78,71 \%$ \\
\hline & & $\begin{array}{l}\text { Bertanya dan Menjawab } \\
\text { Pertanyaan }\end{array}$ & $64,52 \%$ & $76,77 \%$ & $80,00 \%$ \\
\hline 2 & $\begin{array}{l}\text { Basic Support } \\
\text { (membangun } \\
\text { keterampilan dasar) }\end{array}$ & $\begin{array}{l}\text { Mengobservasi dan } \\
\text { Mempertimbangkan Hasil } \\
\text { Observasi }\end{array}$ & $63,87 \%$ & $71,61 \%$ & $76,13 \%$ \\
\hline \multirow[t]{2}{*}{3} & $\begin{array}{l}\text { Inference } \\
\text { (menyimpulkan) }\end{array}$ & $\begin{array}{l}\text { Membuat Induksi dan } \\
\text { Mempertimbangkan Hasil } \\
\text { Induksi }\end{array}$ & $63,23 \%$ & $64,52 \%$ & $70,32 \%$ \\
\hline & & $\begin{array}{l}\text { Membuat dan } \\
\text { Menentukan Hasil } \\
\text { Pertimbangan. }\end{array}$ & $80,00 \%$ & $88,39 \%$ & $93,55 \%$ \\
\hline \multicolumn{3}{|c|}{ Persentase Rata-Rata Kemampuan Berpikir Kritis Siswa } & $72,04 \%$ & $77,96 \%$ & $82,26 \%$ \\
\hline \multicolumn{3}{|c|}{ Kategori } & Cukup & Baik & Baik \\
\hline
\end{tabular}

Berdasarkan tabel 4 di atas persentase rata-rata skor kemampuan berpikir kritis siswa selalu mengalami peningkatan di setiap siklusnya. Pada siklus I persentase rata-rata skor kemampuan berpikir kritis sebesar $72,04 \%$ yang termasuk dalam kategori cukup, pada siklus II mengalami peningkatan yaitu sebesar $77,96 \%$ yang termasuk dalam kategori baik, dan meningkat lagi pada siklus III yaitu sebesar $82,26 \%$ yang termasuk dalam kategori baik. Walaupun persentase nilai rata-rata kemampuan berpikir kritis selalu meningkat pada tiap siklusnya, tapi persentase nilai rata-rata kemampuan berpikir kritis pada siklus I belum memenuhi indikator keberhasilan tindakan yang diharapkan, karena skor pada siklus I tersebut belum mencapai 75 atau belum dalam kategori baik. Namun dari siklus satu ke siklus berikutnya selalu terjadi peningkatan banyaknya siswa yang memperoleh skor kemampuan berpikir kritis dalam kategori baik sampai sangat baik. Dimana pada siklus I banyaknya siswa yang memperoleh skor kemampuan berpikir kritis dalam kategori baik sampai sangat baik sebanyak 19 siswa, lalu meningkat pada siklus II yaitu sebanyak 24 siswa kemudian meningkat lagi pada siklus III yaitu sebanyak 26 siswa. Data persentase rata-rata kemampuan berpikir kritis siswa tiap indikator dari siklus I sampai siklus III dapat dilihat pada gambar 2.

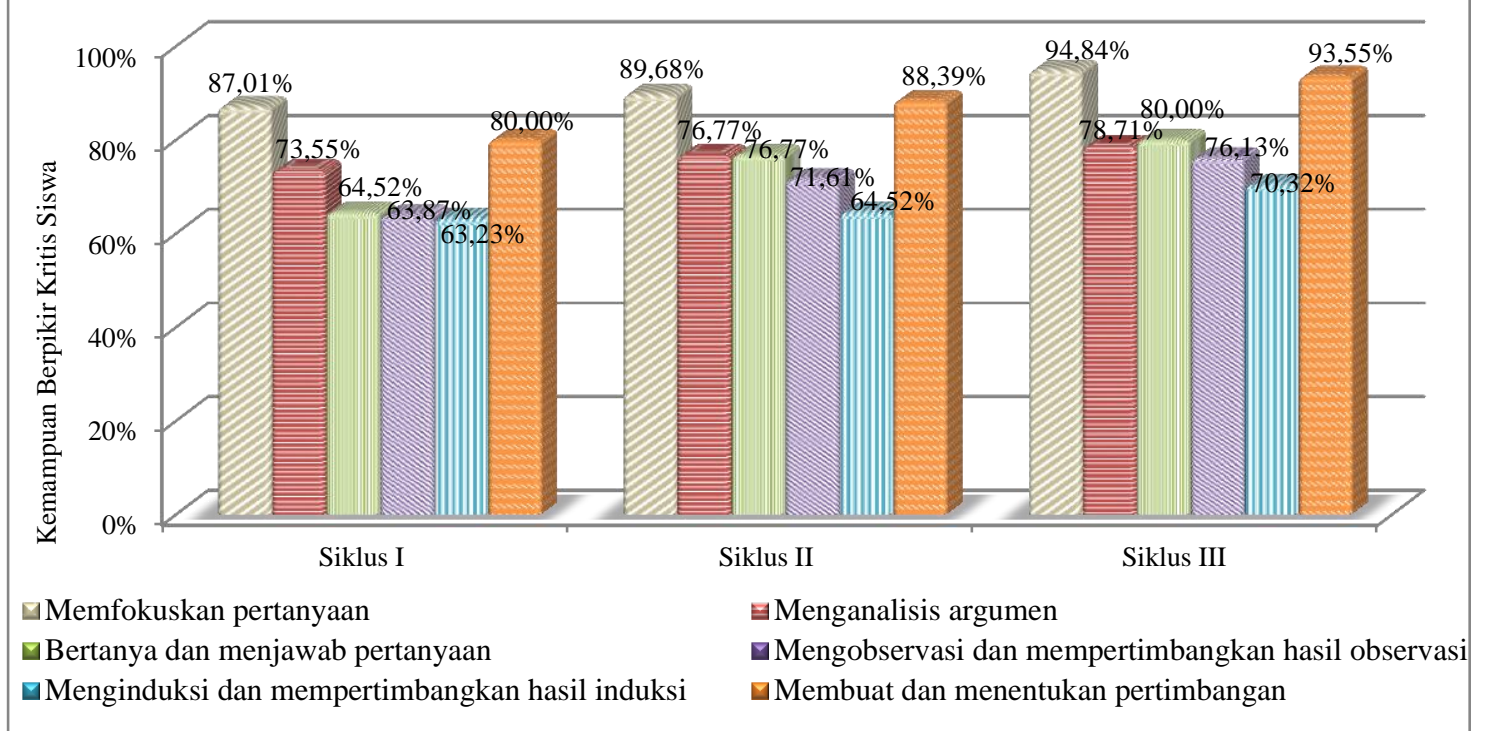

Gambar 2. Grafik Data Persentase Rata-Rata Kemampuan Berpikir Kritis Siswa 
Berdasarkan gambar 2 dapat diketahui bahwa selalu terjadi peningkatan persentase rata-rata kemampuan berpikir kritis siswa di tiap indikator. Kemampuan berpikir kritis yang paling meningkat ada pada indikator memfokuskan pertanyaan serta membuat dan menentukan hasil pertimbangan, dan indikator yang masih perlu untuk ditingkatkan lagi yaitu indikator membuat induksi dan mempertimbangkan hasil induksi. Namun secara keseluruhan selalu terjadi peningkatan persentase kemampuan berpikir kritis siswa dari siklus I ke siklus II dan ke siklus III, dan selalu terjadi peningkatan banyaknya siswa yang memperoleh persentase kemampuan berpikir kritis dalam kualifikasi baik sampai sangat baik. Peningkatan persentase rata-rata kemampuan berpikir kritis ini dikarenakan siswa dilatih untuk berpikir kritis dalam proses pembelajaran model discovery learning dengan pendekatan saintifik dan juga LKS yang digunakan untuk membimbing siswa selama proses pembelajaran didalamnya mengandung indikator-indikator berpikir kritis, selain itu selalu dilakukan refleksi di akhir pembelajaran untuk perbaikan pembelajaran pada siklus berikutnya sehingga hasil yang diperoleh dapat meningkat. Peningkatan kemampuan berpikir kritis ini juga dikarenakan aktivitas belajar siswa yang baik dan selalu meningkat ditiap siklusnya, selain itu aktivitas guru juga sangat berperan penting dalam keberhasilan proses pembelajaran. Bimbingan dan arahan dari guru dapat meningkatkan keterlibatan dan keaktifan siswa selama proses pembelajaran.

Berdasarkan uraian di atas, dapat diketahui bahwa pembelajaran melalui penerapan model discovery learning dengan pendekatan saintifik dapat meningkatkan kemampuan berpikir kritis siswa. Seperti yang dikatakan Windarti, Slameto, \& Widyanti (2018) dimana langkah-langkah dari model discovery learning terbukti mampu untuk meningatkan kemampuan berpikir kritis siswa [10]. Melalui penerapan model discovery learning dengan pendekatan saintifik, siswa dituntut untuk lebih aktif dalam menemukan sendiri konsep dan materi sehingga aktivitas belajar siswa menjadi meningkat, pembelajaran tidak lagi berpusat kepada guru (teacher sentered) melainkan berpusat kepada siswa (student centered) sehingga siswa diberikan kesempatan untuk mempunyai pengalaman yang memungkinkan mereka untuk menemukan prinsip-prinsip atau pengetahuan untuk dirinya sendiri.

Hasil penelitian yang diperoleh sesuai dengan hasil penelitian yang dilakukan oleh Nugrahaeni, Redhana, \& Kartawan (2017) yang menyimpulkan bahwa model pembelajaran discovery learning dapat meningkatkan kemampuan berpikir kritis siswa [5]. Hal ini disebabkan karena proses pembelajaran menggunakan model discovery learning membuat siswa menemukan sendiri jawaban atas permasalahan yang diberikan dengan cara mengkaji, menganalisis, memverifikasi, merumuskan dan membuat kesimpulan dan setiap indikator kemampuan berpikir kritis sudah terpenuhi dalam kegiatan pembelajaran sejalan dengan sintaks yang terdapat dalam model discovery learning yang digunakan.

\section{SIMPULAN DAN SARAN \\ 4.1 Simpulan}

Berdasarkan hasil penelitian yang telah dilakukan, maka dapat ditarik simpulan yaitu: (1) Penerapan discovery learning model dengan pendekatan saintifik dapat meningkatkan kemampuan berpikir kritis siswa kelas XI MAN 2 Kota Bengkulu pada konsep Kalor dan Perpindahan Kalor, dapat dilihat peningkatan persentase rata-rata kemampuan berpikir kritis siswa dari satu siklus ke siklus berikutnya, yaitu persentase rata-rata kemampuan berpikir kritis siswa pada siklus I berada pada katerori cukup, lalu meningkat pada siklus II pada kategori baik, dan kemudian meningkat lagi pada siklus III pada kategori baik. Selain itu, selalu terjadi peningkatan banyaknya siswa yang memperoleh persentase kemampuan berpikir kritis dalam kualifikasi baik sampai sangat baik dari siklus satu ke siklus berikutnya; (2) Penerapan discovery learning model dengan pendekatan saintifik dapat meningkatkan aktivitas belajar siswa kelas XI MAN 2 Kota Bengkulu pada konsep Kalor dan Perpindahan Kalor, pada siklus I, II dan III selalu terjadi perningkatan skor rata-rata aktivitas belajar siswa dan selalu dalam kategori baik. 


\subsection{Saran}

Berdasarkan kesimpulan di atas, dapat disarankan beberapa hal yaitu: (1) Karena model discovery learning hanya dapat dipakai untuk materi tertentu maka sebelum dilakukan pembelajaran, guru disarankan agar mampu memilih dan memilah materi mana yang tepat dan cocok serta dapat diterapkan dalam proses belajar mengajar; (2) Sebelum menggunakan model pembelajaran discovery learning, guru sebaiknya terlebih dahulu mempersiapkan masalah-masalah dalam kehidupan sehari-hari yang menarik dan terkait pada materi pelajaran sehingga siswa akan tertarik mengikuti pelajaran.

\section{DAFTAR PUSTAKA}

[1] Kadri, M., \& Rahmawati, M. (2015). Pengaruh Model Pembelajaran Discovery Learning Terhadap Hasil Belajar Siswa Pada Materi Kalor. Jurnal Ikatan Alumni Fisika Universitas Negeri Medan, Volume 1 No 1, 29-33.

[2] Hardianti, Nurhayati, \& Yani , A. (2015). Peranan Pendekatan Saintifik Terhadap Hasil Belajar Fisika Peserta Didik Kelas X SMA Negeri 1 Lappariaja. Jurnal Sains dan Pendidikan Fisika, Jilid 11 Nomor 1, 34-39.

[3] Kurniasih, I., \& Sani, B. (2014). Sukses Mengimplementasikan Kurikulum 2013. Kata Pena.

[4] Widiasworo, E. (2017). Strategi \& Metode Mengajar Siswa di Luar Kelas (Outdoor Learning). Yogyakarta : AR-Ruzz Media .

[5] Nugrahaeni, A., Redhana , I. W., \& Kartawan , I. A. (2017). Penerapan Model Pembelajaran Discovery Learning Untuk Meningkatkan Kemampuan Berpikir Kritis dan Hasil Belajar Kimia. Jurnal Pendidikan Kimia Indonesia, Volume 1 No 1, 23-29.

[6] Winarso, W., \& Dewi, W. Y. (2017). Berpikir Kritis Siswa Ditinjau dari Gaya Kognitif Visualizer dan Verbalizer dalam Menyelesaikan Masalah Geometri. BETA Jurnal Tadris Matematika, Volume 10 No 2, 117-133.

[7] Agustriana, A., Ningrum , E., \& Somantri , L. (2015). Pengaruh Penggunaan Model Pembelajaran Discovery Learning Terhadap Kemampuan Berpikir Kritis (Penelitian Quasi Eksperimen di Kelas XI IPS SMA Negeri 1 Dukupuntang). Analogi Pendidikan Geografi, Volume 3 No 1, 1-16.

[8] Sapitri, U. E., Kurniawan, Y., \& Sulistri , E. (2016). Penerapan Model Discovry Learning Untuk Meningkatkan Keterampilan Berpikir Kritis Siswa Kelas X Pada Materi Kalor. Jurnal Ilmu Pendidikan Fisika (JIPF), Volume 1 No 2, 64-66.

[9] Istiana, G. A., Catur, A. N., \& Sukardjo. (2015). Penerapan Model Pembelajaran Discovery Learning Untuk Meningkatkan Aktivitas dan Prestasi Belajar Pokok Bahasan Larutan Penyangga Pada Siswa Kelas XI IPA Semester II SMA Negeri 1 Ngemplak. Jurnal Pendidikan Kimia, Volume 4(No 2), 65-73.

[10] Windarti, Y., Slameto, \& Widyanti, E. (2018). Peningkatan Kemampuan Berpikir Kritis dan Hasil Belajar Melalui Penerapan Model Discovery Learning Dalam Pembelajaran Tematik Kelas 4SD. Jurnal Pendidikan Berkarakter, Vol. 1(No.1), 150-155. 